\title{
Effectiveness of Sesame Seeds Cookies (Sesamum Indicum Seeds) Combination of Iron In Increasing Hemoglobine Levels of Adolescents
}

\author{
Yuliani Tangko*, Ari Suwondo, Supriyana \\ Semarang Health Polytechnic, Central Java, Indonesia \\ *yulianitangko739@gmail.com
}

\begin{abstract}
Female adolescent anemia is a health problem in Indonesia, with a prevalence of one third of the female population. The government program, namely the provision of $\mathrm{Fe}$ tablets, has not been able to reduce the prevalence of anemia. The cause is due to side effects such as nausea, vomiting, dizziness, so that people do not obey their consumption. One of the sources of vegetable iron, namely sesame seeds which have no side effects which can be used as an iron companion to treat anemia.

Objective: To analyze the effectiveness of sesame seed cookies in increasing hemoglobin levels of anemic adolescent girls.

Method: The research design was quasy experiment pretest - posttest with control group design with purposive sampling technique. The sample consisted of 42 people divided into 2, namely the intervention group 21 people and the control group 21 people, the intervention group was given $91 \mathrm{mg}$ sesame seed cookies combination of $\mathrm{Fe}$ tablets, the control group was only given Fe tablets each given every day for 10 days. Data analysis used independent test, paired test, Mann Whitney test and Wilcoxon sign rank test.

Results: Sesame seed cookies $91 \mathrm{mg}$ Fe tablet combination proved to significantly increase hemoglobin levels p value $=0.013<0.05$.

Conclusion: Sesame seeds contain various important nutrients, namely iron, folate, flavonoids, copper and other nutrients that play a role in increasing hemoglobin levels as a companion to iron in overcoming anemia.
\end{abstract}

Keywords : Anemia, Sesame Seeds, Adolescent Girls

Received June 15, 2020; Revised July 8, 2020; Accepted August 12, 2020 


\section{STRADA Jurnal Ilmiah Kesehatan}

DOI: $10.30994 /$ sjik.v9i2.368

ISSN: 2252-3847 (print); 2614-350X (online)

Vol.9 No.2 November 2020 Page.700-707

\section{BACKGROUND}

Anemia is a condition where the number of erythrocytes or hemoglobin levels in the blood is less than normal (Wiknjosastro G.H, 2009). Anemia occurs due to lack of one or more essential nutrients, especially iron, which is an essential mineral in the formation of hemoglobin and myoglobin to transport oxygen to all body tissues (Patimah, 2017).

Until now, anemia in adolescent girls is a world health problem, especially in developing countries with a prevalence of 43\% (Sudikno, 2016) (Widjaja, Widjaja, Santoso, Wonggokusuma, \& Oktaviati, 2014). In Southeast Asia 17-90\%(Fikawati S., 2017). India 56\% (Aguayo, Paintal, \& Singh, 2013)(Siva, Sobha, \& Manjula, 2016). The results of the 2018 Basic Health Research show that the prevalence of anemia in adolescent girls in Indonesia was $37.1 \%$ in 2013 and experienced a fairly high increase in 2018 to $48.9 \% .9$ The proportion of anemia occurs mostly in age group 15-34 years, especially in pregnant women and girls (Muwakhidah, 2009)(Center of Data and Information, 2014).

One of the causes of anemia is a lack of iron in food intake. Anemia that occurs in adolescent girls is higher than that of boys because girls experience menstruation every month and tend to maintain ideal body weight without considering balanced nutrition or iron needs (Satriani, 2018).

Anemia in adolescent girls will have an impact on disruption of brain development, decreased concentration which will lead to decreased performance. In the future, the risk of experiencing anemia during pregnancy will affect the growth and development of the fetus in the womb, LBW, stunting and has the potential to cause complications of pregnancy and childbirth, and even cause death to mothers and babies (Fadila \& Kurniawati, 2018).

The government program by providing Fe tablets has been implemented since 2016 but has not been able to reduce the prevalence of anemia in Indonesia. One of the causes is the lack of compliance with Fe tablets due to side effects such as nausea, vomiting, dizziness, obstipasi (Patimah, 2017)(Astuti C.P, Widyawati M.N, 2017). As an alternative to overcome this problem by utilizing sesame seeds as a non-pharmacological substance that does not have side effects and as a dietary intake of vegetable iron. Sesame seeds can be used as a companion to iron supplements because they contain a variety of nutrients including protein, antioxidants, flavonoids, vitamin $\mathrm{E}$, omega 3, zinc, folate, Fe, copper (United States Deparement Of Agriculture, 2019). which is processed into nutritious food in the form of sesame seed cookies.

Based on the background and problem identification, this study aims to analyze the effectiveness of sesame seed cookies in overcoming anemia in adolescent girls.

\section{METHODS}

This study used a quasy experimental design with a pretest-postest approach with control group design. The independent variable in this study was sesame seed cookies and the dependent variable was hemoglobin level. The population in this study were all young women in SMP, SMK and MA Pesantren Pembangunan Muhammadiyah, Tana Toraja Regency. The sample consisted of 42 people who were divided into 2 groups, namely 21 intervention groups and 21 control groups. Sampling was done by using purposive sampling technique, namely by giving lottery numbers to respondents who had previously been screened based on inclusion criteria, namely young women aged 15-18 years, adolescent girls who were anemia (hemoglobin level $<12 \mathrm{~g} / \mathrm{dl}$ ). In the intervention group were given $91 \mathrm{mg}$ sesame seed cookies ( 7 pieces) combination of Fe tablets, while in the 


\section{STRADA Jurnal Ilmiah Kesehatan}

DOI: $10.30994 /$ sjik.v9i2.368

ISSN: 2252-3847 (print); 2614-350X (online)

Vol.9 No.2 November 2020 Page.700-707

control group were only given Fe tablets which were consumed every day for 10 days. All respondents have previously given their consent and are willing to participate in this research voluntarily. This study was approved by the ethics committee of the Moewardi Hospital Surakarta with the ethical number 058 / I / HREC / 2020. The instruments used were observation books, digital scales, speedometers and hematology analyzers. . Data analysis used univariate and bivariate analysis using Paired Sample T Test, Mann Whithney, Wilcoxon Sign Rank Test and Independent Test. This research was conducted on February 17-29, 2020.

\section{RESULTS}

1. Analysis of the Distribution of Characteristics of Respondents in the Intervention and Control Groups.

Table 1. Frequency distribution of respondents' age and BMI in the intervention group and Control Group.

\begin{tabular}{llllll}
\hline \multirow{2}{*}{ Characteristics } & \multicolumn{2}{l}{ Intervention Group $(\mathbf{n = 2 1})$} & \multicolumn{2}{l}{ Control Group $(\mathbf{n}=\mathbf{2 1})$} & $\begin{array}{c}\boldsymbol{p} \text { - } \\
\text { value }\end{array}$ \\
\cline { 2 - 6 } & Mean \pm SD & Min-max & Mean \pm SD & Min-max & \\
\hline Respondent Age & $15.90 \pm 0.995$ & $15-18$ & $16.19 \pm 0.928$ & $15-18$ & 0.610 \\
\hline BMI & $20,852 \pm 2,7502$ & $15.5-27.4$ & $20,338 \pm 2,192$ & $17.7-24.8$ & 0.443 \\
\hline
\end{tabular}

Table 1 shows that there is no difference in the age of the respondents in the intervention group and the control group with a $p$ value of 0.255 ( $p>0.05)$. Each group has a homogeneous age or equal to $p$ value of 0.610 ( $p>0.05)$, the age of the intervention group is 15.90 or an average age of 16 years, and the age of the control group is 16.19 which is also the same. approaching 16 years of age. The nutritional status of BMI between the two groups was also not different with a $p$ value of 0.443 ( $p>0.05$ ), which indicates that the BMI of the intervention group and the control group came from a homogeneous population. The average BMI score of the intervention group was 20,852 and the control group was 20,338. All scores are within the normal category score range.

2. Analysis of the effectiveness of sesame seed cookies in the intervention group and control group before and after treatment.

Table 2. Analysis of the Effectiveness of the Combination Sesame Seeds Cookies (sesame seeds indicum) Fe Tablets to Increase Hemoglobin Levels.

\begin{tabular}{|c|c|c|c|c|c|c|c|c|}
\hline Variable & Pre & pvalue & Post & pvalue & $\Delta$ & pvalue & $\begin{array}{l}\text { Differenc } \\
\text { e } \\
\text { Incremen } \\
\mathbf{t} \\
\quad(\%) \\
\end{array}$ & $p$ value \\
\hline Hemoglobin & $\begin{array}{l}\text { Mean } \pm \\
\text { SD }\end{array}$ & & $\begin{array}{l}\text { Mean } \pm \\
\text { SD }\end{array}$ & & $\begin{array}{l}\text { Mean } \pm \\
\text { SD }\end{array}$ & & & \\
\hline \multirow[t]{2}{*}{$\begin{array}{l}\text { Interventio } \\
\text { n }\end{array}$} & $\begin{array}{l}11,000 \\
\pm \\
0.7014\end{array}$ & & $\begin{array}{l}12.614 \pm \\
0.677\end{array}$ & & $\begin{array}{l}1,600 \pm \\
0.3619\end{array}$ & & 14.54 & $0,000 * * *$ \\
\hline & & $0.930 * *$ & & $0.013 *$ & & $\begin{array}{c}0,000 \\
*\end{array}$ & & \\
\hline
\end{tabular}




\section{STRADA Jurnal Ilmiah Kesehatan}

DOI: $10.30994 /$ sjik.v9i2.368

ISSN: 2252-3847 (print); 2614-350X (online)

Vol.9 No.2 November 2020 Page.700-707

\begin{tabular}{llllll}
\hline Control & 10.995 & $11.933 \pm$ & $1,000 \pm$ & 9,10 & $0,000 * * * *$ \\
& \pm & 0.986 & 0.523 & & \\
& 0.7984 & & & & \\
\hline
\end{tabular}

Table 2 shows the results of the Mann Whitney test analysis data pre (before treatment) obtained $\mathrm{p}$ value 0.930 ( $\mathrm{p}>0.05)$, which means that the mean hemoglobin levels in the intervention group and the control group were not different. In the post data (after treatment) the results of the independent test analysis obtained a $p$ value of 0.013 ( $p$ <0.05), which means that the average hemoglobin level in the intervention group and the control group was different. Analysis of the delta independent $t$ test $(\Delta)$ obtained a $p$ value of $0.000(p<0.05)$, which means that there is a difference in the mean change in hemoglobin levels in the intervention group and the control group.

The conclusion from the unpaired data analysis showed that the group given the $91 \mathrm{mg}$ sesame seed cookies combination with Fe tablets had a higher hemoglobin level, namely $12.614 \mathrm{~g} / \mathrm{dl}$ compared to the hemoglobin level in the control group which was only given Fe tablets, namely 11,933 gr / dl.

The results of the analysis of the mean changes in hemoglobin levels in the two groups showed a higher increase in the group that was given $91 \mathrm{mg}$ sesame seeds indicum combination of $60 \mathrm{mg}$ Fe tablet, namely 1,600 compared to the control group which was only given Fe tablets which increased only 1, so the seed cookies Sesame can act as an iron supplement to further increase hemoglobin levels in anemic adolescent girls.

Paired sample test results, namely the comparison before and after treatment with paired $t$ test analysis in the intervention group obtained a $p$ value of $0.000(p<0.05)$, which means that there is a significant difference in the average hemoglobin levels before and after treatment. The results of the analysis of the Wilcoxon sign rank test in the control group obtained $\mathrm{p}$ value 0.000 ( $\mathrm{p}<0.05)$, which means that there is a significant difference in the average hemoglobin levels before and after treatment.

The conclusion from the pairwise data analysis in both groups was that both groups experienced an increase in hemoglobin levels but an increase in hemoglobin levels in the group given the $91 \mathrm{mg}$ sesame seed cookies combination of Fe tablets showed better results than the increase in hemoglobin levels in the control group only given Fe tablets. This is known from the difference in the mean hemoglobin of each group.

The complete increase in the average hemoglobin level is presented in the following figure: 


\section{STRADA Jurnal Ilmiah Kesehatan}

DOI: $10.30994 /$ sjik.v9i2.368

ISSN: 2252-3847 (print); 2614-350X (online)

Vol.9 No.2 November 2020 Page.700-707

Graph 1. Average Increase in Hemoglobin Levels.

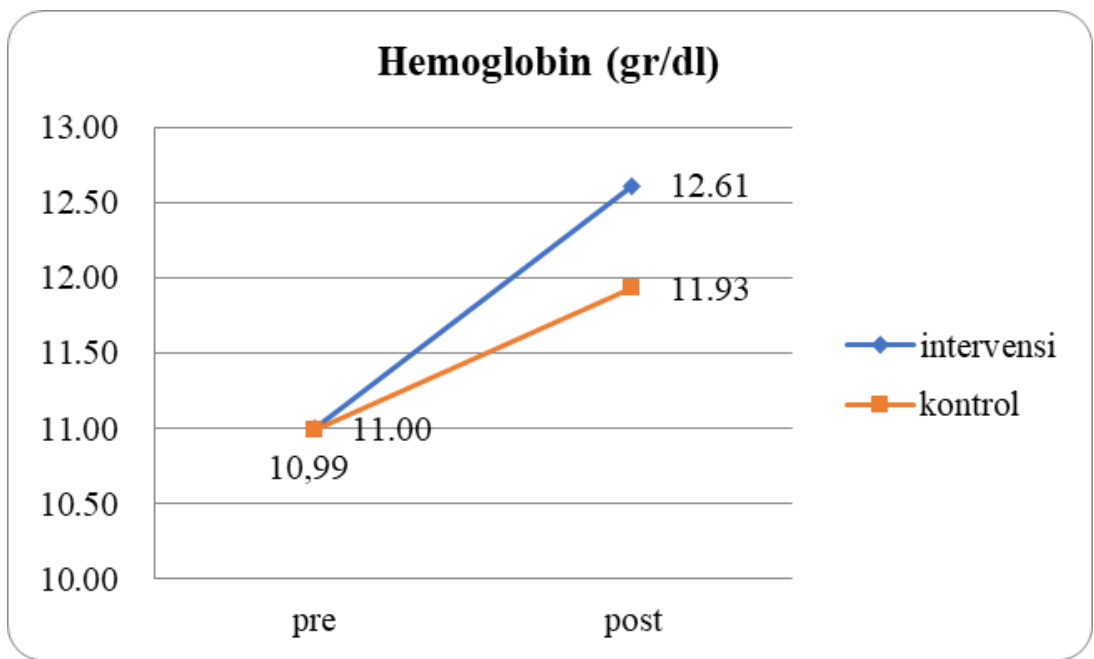

\section{DISCUSSION}

Anemia in young women is a health problem to date. Anemia in adolescent girls is caused by various factors (Hellaliaghdam et al., 2010)(Adamu et al., 2017) including lack of food intake, chronic malaria bleeding(Gunaratna et al., 2015), length of menstruation (Satriani, 2018) and others. Efforts to overcome anemia include health education, iron supplements, intake of vegetable or animal iron (Allen et al., 2017). This study provides an intervention with the intake of vegetable iron as a non-pharmacological food, namely sesame seeds which are processed into sesame seed cookies so that they can be used as a snack for teenage girls to consume as additional iron to help overcome anemia.

The provision of $91 \mathrm{mg}$ sesame seed cookies with a combination of Fe tablets to 21 people in the intervention group which was given every day for 10 days showed an increase in hemoglobin levels for anemic adolescent girls in SMP, SMK and Madarasah Aliyah Pesantren Pembangunan Muhammadiyah, Tana Toraja Regency. Changes in hemoglobin levels in the intervention group and the control group both experienced an increase, but the increase was more in the group given the combination of Fe tablet sesame seed cookies compared to the control group that was given only $\mathrm{Fe}$ tablets. Where the intervention group experienced an increase in hemoglobin levels by $12,614 \mathrm{~g} / \mathrm{dl}$, while the control group that only consumed Fe tablets experienced an increase in hemoglobin levels by an average of $11,933 \mathrm{~g} / \mathrm{dl}$, with a value of $\mathrm{p}=0.013<0.05$. The results showed that sesame seeds can increase hemoglobin levels. Teenage girls who took Fe tablets combined with $91 \mathrm{mg}$ sesame seed cookies had higher hemoglobin levels 1,600 than girls who were only given $1,000 \mathrm{Fe}$ tablets with $\mathrm{p}=0,000$.

This is in line with research conducted on albino rats where sesame seed extract induced an increase in hemoglobin and red blood cell levels (Ruckmani et al., 2018). This is because sesame seeds contain a variety of essential nutrients to increase hemoglobin levels, including flavonoids that can ward off free radicals. The flavonoid content is also supported by the results of previous studies which concluded that all parts contain a large number of flavonoids, while seeds have the highest levels of flavonoids. Flavonoids are included in the polyphenol group of compounds. Polyphenols are plant compounds with high levels of antioxidant activity due to their ability to neutralize and extinguish free radicals (Mbaebie, Omosun, Uti, \& Oyedemi, 2010). Sesame seeds also contain sesamun 


\section{STRADA Jurnal Ilmiah Kesehatan}

DOI: $10.30994 /$ sjik.v9i2.368

ISSN: 2252-3847 (print); 2614-350X (online)

Vol.9 No.2 November 2020 Page.700-707

and sesamolin which show that sesame extract can reduce the weakening of blood vessel walls by suppressing the degradation of collagen and elastin fibers (Kugo et al., 2019). In addition, sesame seeds contain proteins which play an important role in the formation of cells and blood (Prasad MN, KR, \& S. Prasad, 2012)(Meisyahputri \& Ardiaria, 2017)(Li et al., 2014), and vitamin E for maintaining healthy blood vessels and cell membrane stability (Sunuta Almatsier, 2012). Other important ingredients in sesame seeds are antioxidants that can protect the body from various disease conditions because of their ability to neutralize the effects of free radicals (Kumar, Kamboj, \& Sisodia, 2011).

In 100 grams of sesame seeds contain $14.55 \mathrm{mg}$ of Fe (iron), 21.773 grams of total polyunsaturated fatty acids, $97 \mathrm{mg}$ of folate, 17.73 grams of protein, $0.25 \mathrm{mg}$ of vitamin $\mathrm{E}$ and several other nutrients (United States Deparement Of Agriculture, 2019). Iron in sesame seeds is needed for the formation and function of red blood cells and has several essential functions in the body, namely as a means of transporting oxygen from the lungs to body tissues, transporting electrons in cells and is an integral part of enzyme reactions. in body tissues (Prasad MN et al., 2012), Iron is also very important to form heme in hemoglobin, myoglobin, cytochrome, catalase and feroksidase.(Patimah, 2017). The iron released from the hem of the porphyrin leaves is converted to bilirubin. Iron bound to transferrin binds to transferrin receptors, excreted on the surface of red blood cell precursors to form hemoglobin. Hemoglobin is iron that binds to proteins in erythrocytes which bind oxygen from the lungs and distribute it to the cellular level. Meanwhile, transferrin is a protein involved in the transport of iron in the blood circulation (Fikawati S, 2017).

The results of data analysis in the intervention group and the control group both experienced an increase in hemoglobin levels between the pretest and posttest. However, the intervention group that was given sesame seed cookies with a combination of $\mathrm{Fe}$ tablets experienced an increase more than the control group.

Apart from iron, sesame seeds (sesamum indicum seeds) also contain folic acid which is a bond that acts as a coenzyme in the transportation of single fractions in amino acid metabolism and in the synthesis of nucleic acids which can supply folic acid to the body.

\section{CONCLUSION.}

The provision of sesamum indicum seeds cookies of $91 \mathrm{mg}$ combination of Fe tablets given to anemic adolescent girls every day for 10 days at SMP, SMK and MA Pesantren Muhammadiyah, Tana Toraja Regency was significantly able to increase hemoglobin levels with $\mathrm{p}$ value $=0.013$.

\section{REFERENCES}

Adamu, A. L., Crampin, A., Kayuni, N., Amberbir, A., Koole, O., Phiri, A., ... Fine, P. (2017). Prevalence and risk factors for anemia severity and type in Malawian men and women: Urban and rural differences. Population Health Metrics, 15(1), 1-15. https://doi.org/10.1186/s12963-017-0128-2

Aguayo, V. M., Paintal, K., \& Singh, G. (2013). The Adolescent Girls' Anaemia Control Programme: A decade of programming experience to break the inter-generational cycle of malnutrition in India. Public Health Nutrition, 16(9), 1667-1676. https://doi.org/10.1017/S1368980012005587

Allen, A., Allen, S., Rodrigo, R., Perera, L., Shao, W., Li, C., ... Premawardhena, A. (2017). Iron status and anaemia in Sri Lankan secondary school children: A crosssectional

survey.

$P L o S$

$O N E$,

$12(11)$,

$1-14$. 


\section{STRADA Jurnal Ilmiah Kesehatan}

DOI: $10.30994 /$ sjik.v9i2.368

ISSN: 2252-3847 (print); 2614-350X (online)

Vol.9 No.2 November 2020 Page.700-707

https://doi.org/10.1371/journal.pone.0188110

Astuti C.P, Widyawati M.N, P. S. . (2017). The Effect Of Iron Polymaltose Complex Tablet Administration To Increase Hemoglobin Level Among Pregnant Women With Anemia. 2nd International Conference on Applied Science and Health, 246-251.

Center of Data and Information, M. of H. R. of I. (2014). Maternal Healths Situation in Indonesia.

Fadila, I., \& Kurniawati, H. (2018). Upaya Pencegahan Anemia Pada Remaja Puteri Sebagai Pilar Menuju Peningkatan Kesehatan Ibu. Prosiding Seminar Nasional FMIPA, 78-89.

Fikawati S., S. A. V. A. (2017). Gizi Anak dan Remaja. Jakarta: Raja Grafindo Persada.

Gunaratna, N. S., Masanja, H., Mrema, S., Levira, F., Spiegelman, D., Hertzmark, E., ... Fawzi, W. (2015). Multivitamin and iron supplementation to prevent periconceptional anemia in rural Tanzanian women: A randomized, controlled trial. PLoS ONE, 10(4), 1-15. https://doi.org/10.1371/journal.pone.0121552

Hellaliaghdam, H., Mohammadzadeh, H., Hemmingsson, T., Melin, B., Allebeck, P., Lundberg, I., ... Education, M. (2010). Feasibility and effect of life skills building education and multiple micronutrient supplements versus the standard of care on anemia among non-pregnant adolescent and young Pakistani women (15-24 years): a prospective, populationbased cluster-randomized . Intelligence (Vol. 7). https://doi.org/10.1192/s0368315x00238942

Kugo, H., Miyamoto, C., Sawaragi, A., Hoshino, K., Hamatani, Y., Matsumura, S., ... Zaima, N. (2019). Sesame extract attenuates the degradation of collagen and elastin fibers in the vascular walls of nicotine-administered mice. Journal of Oleo Science, 68(1), 79-85. https://doi.org/10.5650/jos.ess 18200

Kumar, M., Kamboj, A., \& Sisodia, S. S. (2011). Hepatoprotective Activity Of Sesamum Indicum Linn . Against Ccl 4 -Induced Hepatic Damage In Rats, 2(2), 710-715.

Li, C., Miao, H., Wei, L., Zhang, T., Han, X., \& Zhang, H. (2014). Association mapping of seed oil and protein content in Sesamum indicum L. using SSR markers. PLoS ONE, 9(8). https://doi.org/10.1371/journal.pone.0105757

Mbaebie, B., Omosun, G., Uti, A., \& Oyedemi, S. (2010). Chemical Composition of Sesamum indicum L. ( Sesame) Grown in Southeastern Nigeria and the Physicochemical Properties of the Seed Oil, 1-5.

Meisyahputri, B., \& Ardiaria, M. (2017). Pengaruh pemberian kombinasi minyak rami dengan minyak wijen terhadap kadar kolesterol high density lipoprotein (HDL) pada tikus sprague dawley dislipidemia. Journal of Nutrition College, 6(1), 35. https://doi.org/10.14710/jnc.v6i1.16890

Muwakhidah. (2009). Efek Suplementasi Fe, Asam Folat Dan Vitamin B 12 Terhadap Peningkatan Kadar Hemoglobin (Hb) Pada Pekerja Wanita (Di Kabupaten Sukoharjo). (thesis). Semarang Universitas Diponegoro. https://doi.org/10.1111/17517915.12026

Patimah, S. (2017). Gizi Remaja Puteri Plus 1000 Hari Pertama Kehidupan. Bandung: Refika Aditama.

Prasad MN, N., KR, S., \& S. Prasad, D. (2012). A Review on Nutritional and Nutraceutical Properties of Sesame. Journal of Nutrition \& Food Sciences, 02(02). https://doi.org/10.4172/2155-9600.1000127

Ruckmani, A., Meti, V., Vijayashree, R., Arunkumar, R., Konda, V. R., Prabhu, L., ... Devi, S. (2018). Anti-rheumatoid activity of ethanolic extract of Sesamum indicum seed extract in Freund's complete adjuvant induced arthritis in Wistar albino rats. 


\section{STRADA Jurnal Ilmiah Kesehatan}

DOI: $10.30994 /$ sjik.v9i2.368

ISSN: 2252-3847 (print); 2614-350X (online)

Vol.9 No.2 November 2020 Page.700-707

Journal of Traditional and Complementary Medicine, 8(3), 377-386. https://doi.org/10.1016/j.jtcme.2017.06.003

Satriani. (2018). Analisis Determinan Anemia Pada Remaja Putri (15-18 Tahun) di Kecamatan Tamalate Kabupaten Jeneponto (thesis). Makassar. Universitas Hasanuddin.

Sitti Patimah. (2017). Gizi Remaja Putri Plus 1000 Hari Pertama Kehidupan. (A. Suzana, Ed.) (Pertama). Bandung.

Siva, P. M., Sobha, A., \& Manjula, V. D. (2016). Prevalence of Anaemia and Its Associated Risk Factors Among Adolescent Girls of Central Kerala. Journal of Clinical and Diagnostic Research, 10(11), LC19-LC23. https://doi.org/10.7860/JCDR/2016/20939.8938

Sudikno, S. (2016). Prevalensi dan Faktor Risiko Anemia Pada Wanita Usia Subur Di Rumah Tangga Miskin Di Kabupaten Tasikmalaya Dan Ciamis Provinsi Jawa Barat. Jurnal Kesehatan Reproduksi, 7(2), 71-82.

Sunuta Almatsier. (2012). Prinsip Dasar Ilmu Gizi. Jakarta Gramedia Pustaka Umum.

United States Deparement Of Agriculture. (2019). National Nutrien DatabaseFor Standart Reference Legancy Release (Sesame Seeds).

Widjaja, I. R., Widjaja, F. F., Santoso, L. A., Wonggokusuma, E., \& Oktaviati, O. (2014). Anemia Among Children and Adolescents In a Rural Area. Paediatrica Indonesiana, 54(2), 88. https://doi.org/10.14238/pi54.2.2014.88-93

Wiknjosastro G.H. (2009). Ilmu Kebidanan. Jakarta: Yayasan Bina Pustaka. 